\title{
Ant predation on intertidal polychaetes in a SW Atlantic estuary
}

\author{
Gabriela Palomo*, Paulina Martinetto, Claudio Perez, Oscar Iribarne \\ Departamento de Biología (FCEyN), Universidad Nacional de Mar del Plata, CC 573 Correo Central (7600), \\ Mar del Plata, Argentina
}

\begin{abstract}
Polychaetes in soft-bottom intertidal habitats of the Mar Chiquita coastal lagoon $\left(38^{\circ} 00^{\prime} \mathrm{S}, 57^{\circ} 30^{\prime} \mathrm{W}\right.$, Argentina) are the prey of shorebirds, fishes and crabs. Based on $3 \mathrm{yr}$ of field sampling, we observed that the fire ant Solenopsis richteri is another important predator of polychaetes (mostly Laeonereis acuta) during the summer (December to March). Ants use intertidal areas adjacent to terrestrial habitats which have well-developed soils and are characterized by inland vegetation (i.e. pampas grasses), but appear to be excluded from habitats with the burrowing crab Chasmagnathus granulata. Ants build intertidal galleries perpendicular to the shoreline that are used to transport polychaetes to the nest. The ants attacked the polychaetes in burrows with diameters larger than their own abdomen. They selected larger polychaete sizes, attacking up to $66 \%$ of the polychaetes in the high intertidal. Based on our observations, and given the wide range of this species and related fire ants, we believe that this terrestrial-marine interaction between fire ants and polychaetes could be a common phenomenon.
\end{abstract}

KEY WORDS: Fire ant · Predation · Polychaetes · Terrestrial-marine interaction Resale or republication not permitted without written consent of the publisher

\section{INTRODUCTION}

Aquatic and terrestrial intertidal predators include many species that often have important effects on their prey populations and community structure (i.e. Virnstein 1977, Woodin 1978, Choat 1982, Quammen 1984). Shorebirds, marine invertebrates and fishes are probably the most common and no doubt the most studied predators in these habitats. However, several well-known terrestrial species frequently forage or scavenge in intertidal areas (see Polis \& Hurd 1996), generating an important exchange of matter and energy across this boundary (Rose \& Polis 1998). These species include mammals, birds and arthropods. For example, the Pampas fox Pseudalopex gymnocercus hunts marine fishes (Langguth 1975, Sheldon 1991), coyotes Canis latrans eat ghost crabs (Polis \& Hurd 1996), Norway rats Rattus norvegicus prey on keyhole limpets Fissurella crassa (Navarrete \& Castilla 1993), scorpions Vaejovis littoralis prey on isopods, spiders, pseudoscorpions, centipedes and beetles (Due \& Polis
1985), the birds South Georgia pipit Anthus antarcticus and European starling Sturnus vulgaris prey on beached marine crustaceans (Burger 1985) and kiskadees Pitangus sulphuratus prey on fiddler crabs (Iribarne \& Martinez 1999). As a result of this rich food source, predator densities in coastal areas are often several times higher than their inland populations (Rose \& Polis 1998).

Ants are terrestrial invertebrates frequently found in coastal or intertidal environments (i.e. Allen et al. 2001a,b). Only a few species (Iridomyrmex pruinosus analis and Brachymyrmex depilaris) are known to be strictly intertidal (Yensen et al. 1980), with adaptations to be able to persist in this habitat (Maitland \& Maitland 1994). However, others like the fire ant Solenopsis invicta are found near pond margins, and occasionally their colonies can float down rivers during flooding and re-establish elsewhere (Tschinkel 1988). Ants often are scavengers, foraging on oceanic debris (Jaffe 1993), but some are active predators. Indeed, there is an increasing frequency of imported fire ant attacks on 
sea turtle nests along the Florida coasts (Wilmers et al. 1996, Moulis 1997, Allen et al. 2001a). These ants feed on eggs and on hatchlings of green Chelonia mydas and loggerhead Caretta caretta turtles (Wilmers et al. 1996), which results in a mortality rate of up to $70 \%$ (Allen et al. 2001a).

The Australian ant Iridomyrmex purpureus forma sanguineus preys on the polychaete Armandia intermedia on sandy beaches, producing up to $30 \%$ mortality (Buckley 1980). In the intertidal habitat of SW Atlantic estuarine environments, we have often observed the fire ant Solenopsis richteri preying on the polychaete Laeonereis acuta (Phyllodocidae: Nereidae). This polychaete is one of the most abundant species of SW Atlantic intertidal environments (Orenzanz \& Estivariz 1971, Olivier et al. 1972a, Palomo \& Iribarne 2000), and lives in burrows connected to the surface at depths of up to $10 \mathrm{~cm}$ (Palomo \& Iribarne 2000). Their habitat includes a variety of sediment types, under a wide range of salinities (1 to 40 ppm; Botto et al. 1998, Gutierrez \& Iribarne 1999, Palomo et al. 1999, Schwindt \& Iribarne 2000). L. acuta is a key prey for neotropical migratory shorebirds (Botto et al. 1998, 2000), and important in the diet of fishes (Martinetto 2001) and crabs (Olivier et al. 1972b, Schwindt et al. 2001).

Depending on the extent and impact of ant predation on this polychaete, there may be important indirect effects on other species. In the present study, we (1) describe the frequency and abundance of ants in the intertidal zone, (2) relate their abundance with coastal environmental features, and (3) evaluate their habitat use, predation rate and prey size selectivity.

\section{MATERIALS AND METHODS}

Study area. The study was conducted at the Mar Chiquita coastal lagoon (Argentina; Fig. 1), from 1999 to 2002. The Mar Chiquita coastal lagoon is a $46 \mathrm{~km}^{2}$ body of brackish water (Fasano et al. 1982) with intertidal mud flats surrounded by an extended marsh dominated by the cordgrass Spartina densiflora (Olivier et al. 1972a, Iribarne et al. 1997), or by pampas grasses dominated by Stenotaphrum secundatum (Cabrera \& Zardini 1993). The lagoon is connected to the sea through a $5 \mathrm{~km}$ channel of typically estuarine characteristics, with salinity between 10 and 37 ppm (Reta et al. 2001) and a tidal range between 0.25 and $1.90 \mathrm{~m}$ (Fasano et al. 1982). Our study was performed in this channel (Fig. 1). The marsh and the intertidal softsediment habitats are also characterized by extended bioturbated patches of the burrowing crab Chasmagnathus granulatus (Iribarne et al. 1997). Their large burrow entrances (up to $15 \mathrm{~cm}$ in diameter, up to $50 \mathrm{~cm}$ deep) work as fine-sediment traps contributing to the generation of soft-sediment crab beds. Organic matter and water content increase in these areas due to the burrowing activities of crabs, since hardness and permeability decrease (Botto \& Iribarne 2000).

Description of ants in the intertidal. To determine the ant species found in the intertidal habitat, 15 ants were collected and identified following Kusnezov (1978). A description of their activities was performed by observations in the intertidal habitat during low tide. To identify intertidal areas used by these ants in the lagoon, transects were carried out at 8 sites (Fig. 1). The intertidal was divided into 3 areas depending on the tidal level: high areas, flooded only at extraordinary tides $(>1 \mathrm{~m})$; mid areas, flooded at high tidal level (between 0.5 and $1 \mathrm{~m}$ ) and low areas, flooded at a tidal level $<0.5 \mathrm{~m}$. Transects were $100 \mathrm{~m}$ in length along the coast and at the 3 intertidal levels. The occurrence of ants and galleries was recorded. The distance between ant galleries and attacked polychaetes was also measured (precision $0.1 \mathrm{~cm}$ ). To determine whether the presence of ants in the intertidal is persistent through time, 10 ant

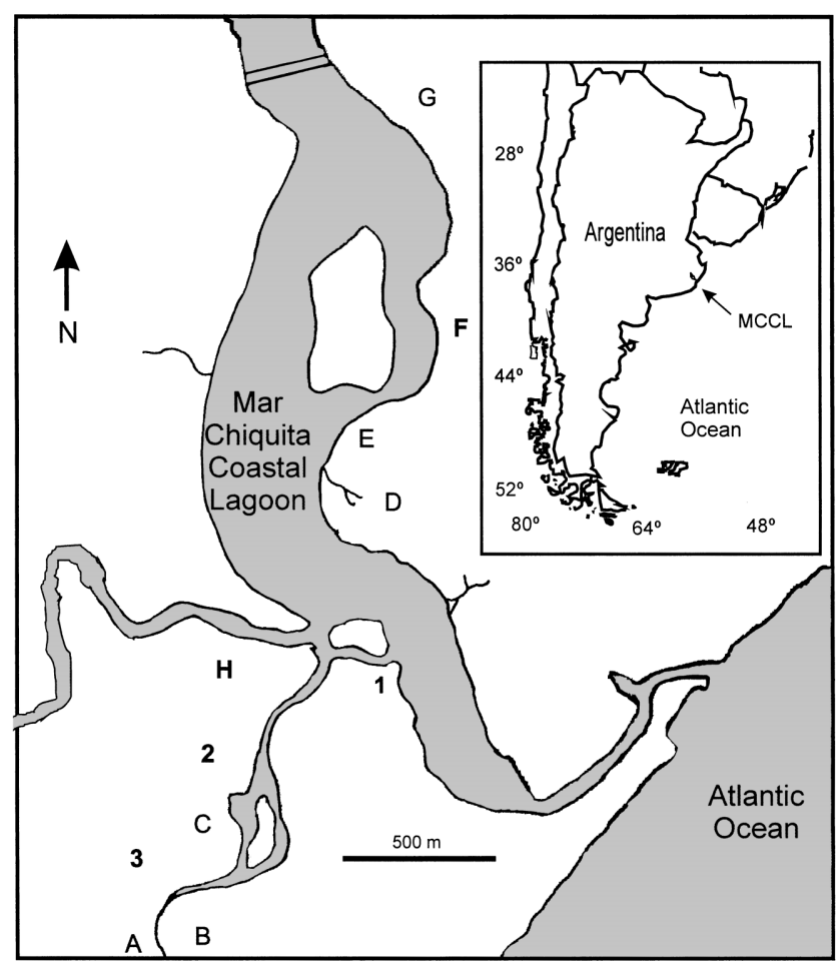

Fig. 1. Mar Chiquita coastal lagoon (MCCL). Sites where salinity was measured during a tidal cycle are indicated by 1 , 2 and 3 . A to $\mathrm{H}$ indicates sites where soil and vegetation were studied. Transects looking for ants were performed from the bridge to the mouth of the lagoon in both coastlines. Inset: location of MCCL in the SW Atlantic 
galleries were marked with stakes and inspected weekly for $2 \mathrm{yr}$.

Relationship between ants and marsh characteristics. To determine whether there was a relationship between the occurrence of ants and the type of coastal environment (i.e. marsh or pampas grass), soil characteristics on vegetated areas close to the studied intertidals were described at each site (Fig. 1). Soil horizons and depth, grain size and color (following Munsell Color Company 2000 soil color charts) were described (FitzPatrick 1984). To achieve a broad description of soils and sediments, grain size distribution was determined by sieve and sedimentation analysis following Carver (1971). Water and organic matter content were also analyzed from sediment samples. Two-way ANOVA was used to determine whether water and organic matter content varied between areas or with depth (Zar 1999).

To assess whether there was any relationship between ant tunnels and the coastal vegetation where ants nest, vegetation characteristics from the 8 sites were described (see Fig. 1). The studied sites encompass the shoreline vegetation in a 7 to $8 \mathrm{~m}$ wide strip, running along the coast. Species composition (following Cabrera \& Zardini 1993) and cover of each sampling area were determined from 3 transects of $10 \mathrm{~m}$ length, running parallel to the coast. Species cover was calculated as: $X_{i}=\left(L_{i} / 10 \mathrm{~m}\right) \times 100$, with $L_{i}$ being the longitude intercepted by species $i$. Mean values were obtained averaging the species cover from each set of 3 sampling units (Magurran 1988). The occurrence of ants and crabs was also recorded. Sites were grouped using cluster analysis, and species presence was used as a grouping variable (Manly 1994).

Prey abundance and fire ant predatory behavior. To estimate prey abundance at the 3 intertidal levels (high, mid and low), we chose Site A, an area where ants were more frequently found (Fig. 1), and took random samples in January 2001. Macroinfauna samples consisted of 10 cores $(10 \mathrm{~cm}$ diameter, $15 \mathrm{~cm}$ depth) from each intertidal level and sieved through a $0.5 \mathrm{~mm}$ mesh screen. Organisms were identified and counted. Differences in density between areas and levels were evaluated with a 1-way ANOVA test (Zar 1999). A posteriori Tukey's tests were used to test for differences between levels (Zar 1999). On the same sampling day and area we recorded the number of ants wandering in the 3 intertidal levels. Ten $0.25 \mathrm{~m}^{2}$ square quadrats were randomly established at each intertidal level during the low level tide and ants found inside the units were counted. Differences in density between areas and levels were evaluated by 1-way ANOVA (Zar 1999).

Although the number of attacked polychaetes in the burrows was recorded for the 3 intertidal levels, no attacked polychaetes were found on mid and low levels during the whole study period. Therefore, to evaluate the ant predation rate, 10 quadrats, $400 \mathrm{~cm}^{2}$, were sampled weekly on the high intertidal level during the period of ant activity and the number of attacked polychaetes was counted. A 1-way ANOVA was performed to detect differences between dates. $\log _{10}$ transformation was necessary to adjust for assumptions. A posteriori Tukey's tests were used to identify differences (Zar 1999). Air temperature was measured each sampling day to evaluate the relationship between weather and ant activity (see Lofgren et al. 1975). Correlation analysis (Zar 1999) was used to evaluate the association between these variables (Zar 1999).

Polychaetes from attacked burrows were collected and measured (total length) to determine whether ants select prey size. The length of broken or partially eaten worms was estimated from the relationship between jaw length and total length (measured when they were completely quiet and elongated). The jaws were measured (accuracy $0.001 \mathrm{~mm}$ ) using a binocular microscope $(40 \times)$. A linear regression model was constructed of the length of intact worms against jaw length (Esselink \& Zwarts 1989). Log transformation was performed to adjust the model (Neter et al. 1990). Sediment core samples as described above were collected from the same intertidal habitat to obtain the size frequency distribution of the available polychaetes. Then, the null hypothesis of no difference in size-frequency distribution between attacked and available polychaetes was evaluated with a Kolmogorov-Smirnov (K-S) test (Conover 1980).

Ants showed a significant selection for larger prey (see 'Results'), which could be due to preference for large sizes or because only larger burrows can be attacked due to the ant size. To evaluate these hypotheses 2 different samplings were performed. First we obtained the relationship between burrow entrance and polychaete length, from 101 polychaetes and their burrows (accuracy $0.02 \mathrm{~mm}$ ). Then, a linear regression model (Neter et al. 1990) was constructed with length of intact worms against burrow entrance diameter. Then we studied the relationship between (1) burrows not affected by ants, (2) burrows that were explored by ants (few ants, 1 or 2 enter a burrow and explore it), and (3) attacked polychaetes in the burrows, and ant abdomen size. The different type of entrances and 68 ant maximum abdomen diameters were measured with calipers (accuracy 0.01). Size frequency distributions of the 3 categories and of the ants' abdomen diameter were compared in a paired mode K-S 2-sample test (Conover 1980). 


\section{RESULTS}

\section{Description of fire ants in the intertidal}

Ants found in intertidal areas were identified as Solenopsis richteri (Kusnezov, 1978). S. richteri was observed exploring the intertidal and entering polychaete burrows. Ants were frequently observed taking sediment out of burrows and carrying away pieces of polychaetes. Occasionally, these ants also collected dead organisms from the coastline, such as crabs or frogs, taking all their soft tissues. This ant was active in several parts of the lagoon, but it was particularly important in one of the tidal creeks (Cangrejito creek; Site A in Fig. 1). Galleries extended from the vegetated area into the intertidal with lengths that varied be-

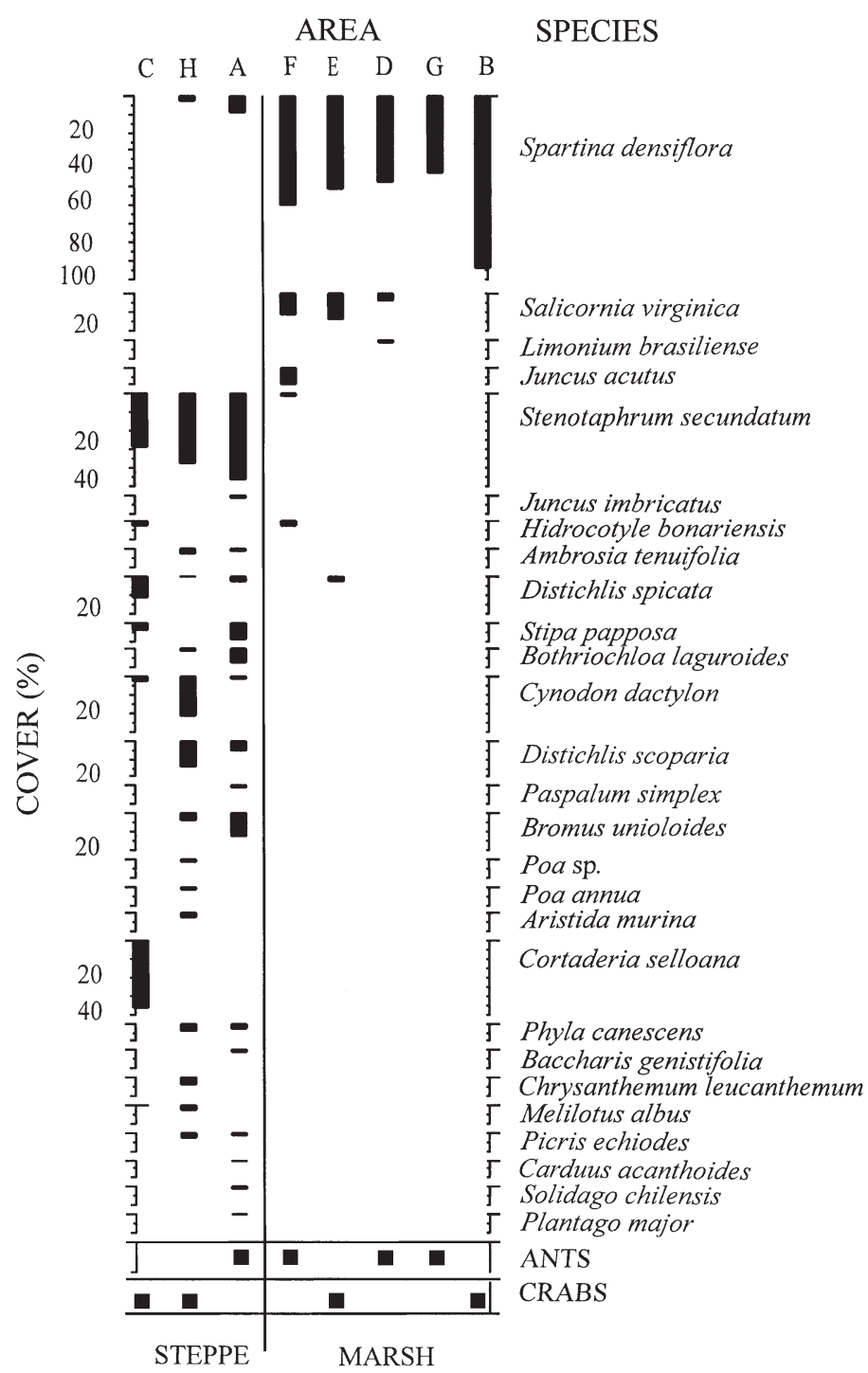

Fig. 2. Vegetation composition and coverage of Sites A to H. Ant and crab presence is also plotted tween 0.5 and $4 \mathrm{~m}$. The largest galleries extended throughout the high intertidal level. They were often straight, perpendicular to the coast and branched out to become a labyrinth as they reached the middle part of the intertidal. Mean diameter of the gallery tunnels was $1 \mathrm{~cm}$, and they were excavated to a depth of 2 to $3 \mathrm{~cm}$, often connected to the surface along their path. These galleries were clearly visible because of excavated sediment on the surface that followed the tunnel path. Tunnels were separated by a distance that ranged from $2.88 \mathrm{~m}(\mathrm{SD}=2)$ at Site $\mathrm{A}$ to $3.47 \mathrm{~m}(\mathrm{SD}=$ 2.04) at Site C. However, at Site A, branches covered almost all the intertidal and galleries were connected. The mean distance between galleries and attacked polychaetes was $5.68 \mathrm{~m}(\mathrm{SD}=4.23 \mathrm{~m}$; maximum distance $15.4 \mathrm{~m}$ ), but all the attacks occurred in the high intertidal level and during the summer period.

When galleries were covered by high tides they frequently collapsed, but $90 \%(n=15)$ were rebuilt by the next low tide. Reconstruction of galleries decreased by the end of the period when ants were active in the intertidal (March 2: $20 \%$, March 6: 10\%, March 14: $0 \%$ ). From one summer to the next, $55 \%$ of the marked galleries were observed in the same place.

\section{Relationship between ants and marsh characteristics}

Soil profiles showed 2 distinct patterns, those with crabs (Sites B, C, E and H) with no defined horizons and areas without crabs (Sites A, D, F and G) where 2 or 3 horizons were clearly identified. Soil color varied between dark grey (Sites A, B, D, E and G), brownish grey (Site C) and black (Sites F and H). A significant interaction between areas and depth (2-way ANOVA, $F_{7}=5.69, \mathrm{p}<0.001$ ) on water content indicated that the pattern of variation of water content was not consistent between areas and sediment depth. Organic matter content showed no significant variation between areas (2-way ANOVA, $\left.F_{7}=0.44, \mathrm{p}>0.05\right)$, depth (2-way ANOVA, $F=0.51$, df $=1, \mathrm{p}>0.05$ ) or the interaction between factors (2-way ANOVA, $F_{7}=0.67, \mathrm{p}>0.05$ ).

Based on vegetation composition and cover, there were 2 distinct communities (Fig. 2). The cluster analysis showed these same 2 groups, one characterized as a salt marsh and the other as a steppe. The salt marsh sites (Sites B, D, E, F and G) are characterized by the presence of halophytic species such as the cordgrass Spartina densiflora, the glasswort Salicornia virginica, the xerophilic shrub Limonium brasiliense and the rush Juncus acutus. In this area $S$. densiflora is the dominant species with cover values higher than $40 \%$, reaching up to $100 \%$ in some cases (Sites B and D). Ants were found in Sites D, F and G and crabs were found in Sites B and E. The second distinct community, 
the humid steppe (Sites A, C and H), showed higher richness, with predominance of grasses (i.e. Stipa papposa, Bothriochloa laguroides, Paspalum simplex, Stenotaphrum secundatum), and some weed species

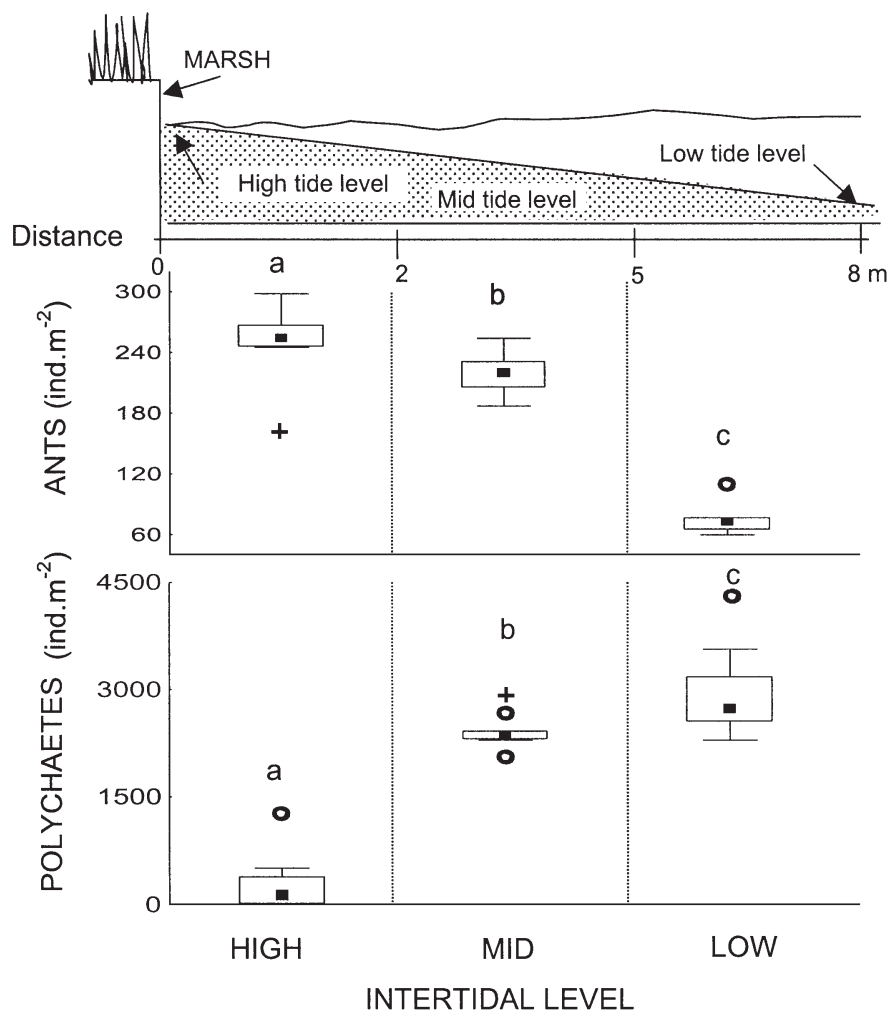

Fig. 3. Solenopsis richteri and Laeonereis acuta. Distance of each intertidal level, and ant and polychaete abundances at each level $( \pm$ SD). Different letters represent significant statistical differences $(\mathrm{p}<0.05)$; O: outlier, +: extreme value
(Melilotus albus, Solidago chilensis, Plantago major, Picris echiodes and Carduus acanthoides). The grass $S$. secundatum is the dominant species, covering more than $30 \%$ of the area. Ants were found only in Site A and crabs in Sites C and H (Fig. 2).

\section{Prey abundance and fire ant predatory behavior}

The most abundant polychaete was Laeonereis acuta. Occasionally, Neanthes succinea and Heteromastus similis were also found, but densities were so low that they were not included in the analysis. The density of polychaetes was higher in the lower intertidal (1-way ANOVA, $F_{2}=54.11, \mathrm{p}<0.001$ ) and decreased towards the upper intertidal (Fig. 3). The density of ants wandering on the intertidal was significantly higher in the high intertidal and decreased in the low intertidal (1-way ANOVA, $F_{2}=85.17, \mathrm{p}<$ 0.001 , Fig. 3). Attacked burrows were only observed at the high intertidal level.

Ant predation rates varied among days (1-way ANOVA test, $F_{17}=13.15, \mathrm{p}<0.001$, Fig. 4$)$. The maximum percentage of attacked burrows was $66.7 \%$ on 20 of February 2001, a minimum of $1.8 \%$ on 24 of February and $0 \%$ on months and days without ant activity (Fig. 4). One ant gallery attacked up to 70.4 (SD = 81.28) burrows $\mathrm{m}^{-2}$ tide $^{-1}$. Correlation analysis between ant activity and air temperature showed that only $26 \%$ $\left(\mathrm{r}^{2}=0.26, \mathrm{n}=180, \mathrm{p}<0.05\right)$ of the variability in ant activity was explained by variation of air temperature.

Polychaetes were always attacked while inside their burrows. Several ants entered the burrow and attacked the polychaete, showing 2 different behaviors; they either cut polychaetes into pieces inside their

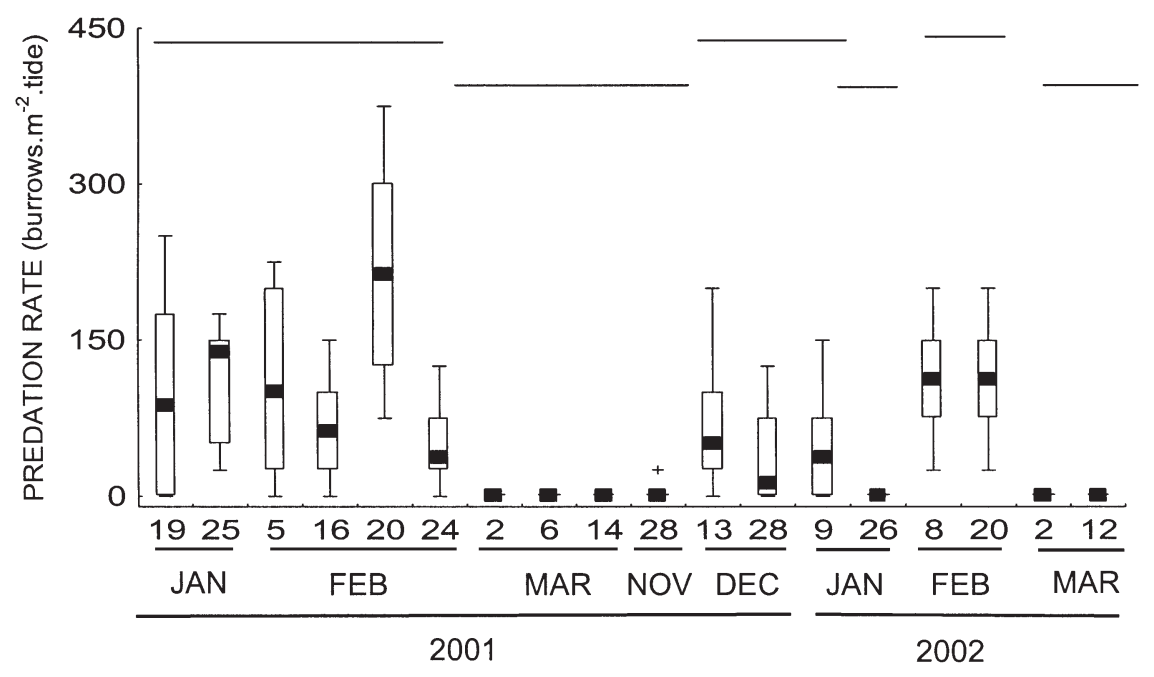

Fig. 4. Solenopsis richteri and Laeonereis acuta. Percentage $( \pm \mathrm{SD})$ of burrows attacked on the high intertidal level during 2001 and 2002. Horizontal lines indicate significant differences between sampling dates 


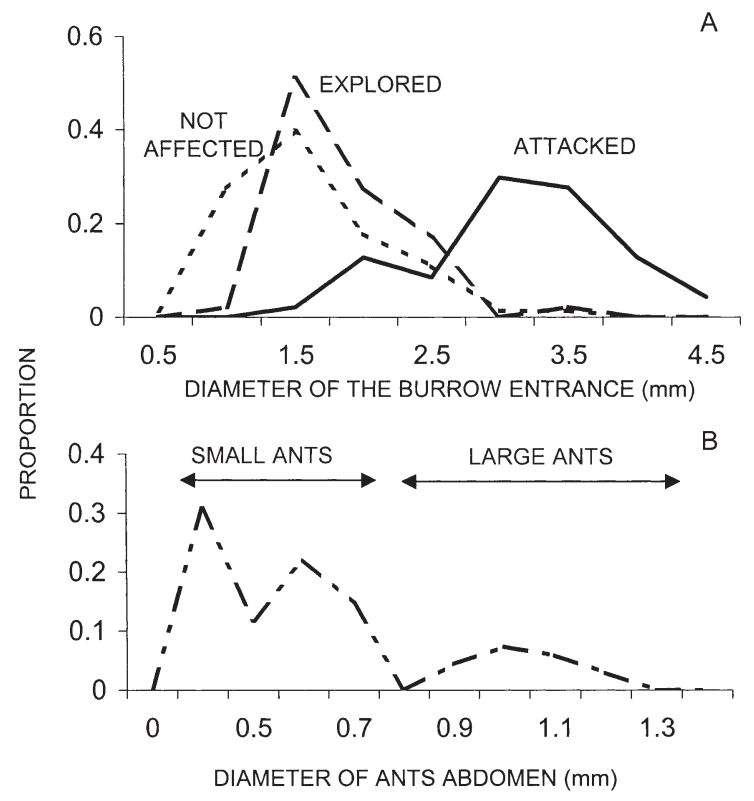

Fig. 5. Solenopsis richteri and Laeonereis acuta. (A) Size frequency distributions of entrance diameter of attacked polychaete burrows (attacked), polychaete burrows where entrance of ants was observed (explored) and not affected polychaete burrows on the intertidal. (B) Size frequency distribution of ant abdomen diameter. Small ants correspond to workers that enter a polychaete burrow. Larger ants correspond to worker ants that attack polychaetes

burrows or dragged the prey outside and cut them into pieces on the surface. Then, the pieces were carried through the galleries to the upper intertidal towards their nests. The sizes of attacked polychaetes were estimated from the relationship: $\log _{10}$ worm length $=$ $0.846+0.129 \times$ jaw length $\left(r^{2}=0.78, n=315, p<0.001\right)$. Available polychaetes at the high intertidal level were significantly smaller than attacked polychaetes (K-S test, $d_{\max }=0.488, \mathrm{n}=38, \mathrm{p}<0.05$ ).

Polychaete burrows were smaller than those used by ants (K-S test, $d_{\max }=0.78, \mathrm{p}<0.001$, Fig. 5). When ants entered and attacked a polychaete burrow, they widened the entrance diameter significantly (K-S test, $d_{\max }=0.76, \mathrm{p}<0.001$, Fig. 5). Ant size-frequency distribution showed 2 distinct modes (Fig. 5). Smaller individuals (abdomen diameter $<0.8$ ) explored the area, entered polychaete burrows (minimum diameter of burrow explored $=0.9 \mathrm{~mm}$ ) and then enlarged the burrow entrance allowing larger ants to enter. The larger ants had an abdomen diameter $>0.8 \mathrm{~mm}$ and they entered burrows with a minimum diameter of $1.42 \mathrm{~mm}$ $(n=50)$. When ant abdomen diameter size-frequency distribution was compared with the diameter of all burrows or with explored burrows, differences in both cases were significant (K-S test, $d_{\max }=0.73, \mathrm{p}<0.001$ and K-S test, $d_{\max }=0.90, \mathrm{p}<0.001$ respectively, Fig. 5). Finally, given that polychaete burrow entrance dia- meter was a good predictor of polychaete length (worm length $=0.915[\mathrm{SD}=0.06]+0.0169[\mathrm{SD}=0.002]$ $\times$ burrow entrance diameter, $\mathrm{r}^{2}=0.42, \mathrm{n}=101, F=$ $67.39, \mathrm{p}<0.001$ ), we can be sure that polychaetes smaller than $15 \mathrm{~mm}$ were not attacked.

\section{DISCUSSION}

This study shows that the fire ant Solenopsis richteri is an important episodic intertidal predator at our study site, since ants are consistently found preying on polychaetes during the summer. Fire ants are widely distributed over South America (Lofgren et al. 1975, Ross \& Trager 1990). This group of species is a member of the subfamily Myrmicinae and is known as the S. saevisima complex, including $S$. invicta and $S$. richteri. Both species are important predators and invaders of agricultural areas in at least 9 southeastern states of the United States (Ross \& Trager 1990), replacing its North American ecological equivalents, S. geminata and S. xyloni (Morrison 2000).

\section{Relationship between ants and marsh characteristics}

Solenopsis richteri was found in different areas, mostly characterized by a well-developed soil structure, with high vegetation richness and characterized as a humid steppe. The salt marsh vegetation is characterized by poorly developed soils, frequently flooded by tides (mainly spring tides). In contrast, humid steppes are found on higher coasts, with welldeveloped soils rarely exposed to tidal flooding. All evidence indicates that the marsh areas are associated with depositional areas of creek meanders, while the humid steppes are associated with erosion processes (Isla \& Gaido 2001). Soil is an important aspect of the S. richteri habitat. It has been described that colonies occur in different soil types (sandy, clayey or silty, Porter et al. 1997, Green et al. 1999), without a correlation between density of colonies and soil type (Wangberg et al. 1980, Porter et al. 1991). Our results showed that ants are associated with well-developed soils, and without crabs. Soil differences between areas with and without crabs are very important. Crab activity generates profound changes in soil structure. Crabs dig burrows up to $1 \mathrm{~m}$ depth and remove up to $3 \mathrm{~kg} \mathrm{~m}^{-2} \mathrm{~d}^{-1}$ of sediment (Iribarne et al. 1997), decreasing soil hardness and surficial percolation rate, and the organic matter content is homogeneously dispersed without horizons (Bortolus \& Iribarne 1999). The ant distribution pattern could be associated with the crab sediment disturbance during burrow maintenance and with the periodic flooding of the marsh areas inhabited by crabs. 


\section{Prey abundance and fire ant predatory behavior}

During low tide, ants explored the intertidal and attacked polychaetes, particularly in the high intertidal zone. The smaller ants that were active at the surface explored burrows and opened the entrances, while the larger ones entered burrows and cut the polychaete into pieces, or took the whole polychaete to the surface, cut it up there, and carried the pieces through their galleries towards the nest. These predatory behaviors were observed only during the summer, approximately 3 mo each year, and can be considered as cases of episodic predation (i.e. Wilson 1994).

Fire ant foraging activity depends on a number of seasonal factors (Porter \& Tschinkel 1987). Temperature is a key factor in its activity (Lofgren et al. 1975), with low temperatures limiting activity (Porter \& Tschinkel 1987). During winter months, brood production is low and protein requirements are decreased, since most protein is fed directly to the larvae (Sorensen et al. 1983). In our study site, ants were not seen in the intertidal during the cold months, but they were found foraging during summer, over a range of temperatures from 18 to $36^{\circ} \mathrm{C}$. A positive correlation was found between air temperature and ant predation rate; however the percentage of variance in ant activity explained by air temperature was low (26\%). At this latitude $\left(38^{\circ} \mathrm{S}\right)$, temperatures are high enough for ants to forage only during the summer ( $25 \%$ of the year). In Georgia $\left(33^{\circ} \mathrm{N}, \mathrm{USA}\right)$, the Solenopsis invicta foraging period persists for $64 \%$ of the year, and in Tallahassee, Florida $\left(30^{\circ} \mathrm{N}, \mathrm{USA}\right)$, for $85 \%$ of the year (Porter \& Tschinkel 1987). The period of foraging activity in warmer latitudes is longer, and is likely an important factor in predicting ant predation impacts.

\section{Impacts of ant predation on the polychaete population}

Our results show that ants can be important predators in intertidal environments. Polychaetes preyed on by ants are also important prey for several shorebirds, juvenile fishes and crabs in this area (Botto et al. 1998, 2000, Martinetto 2001, Schwindt et al. 2001). The impact of ant predation, although restricted to the summer season, is important given that they could attack up to $66 \%$ of polychaete burrows in the high intertidal. In this intertidal habitat, polychaetes live inside burrows with 1 (I-shaped burrow) or 2 connections (Ushaped burrow) to the surface (Palomo \& Iribarne 2000). However, burrow shape changes with polychaete size, and almost all polychaetes larger than $21 \mathrm{~mm}$ have I-shaped burrows (Palomo \& Iribarne 2000). Ants attacked polychaetes larger than $15 \mathrm{~mm}$, thus the attack rate is similar to the real ant predation rate on polychaetes. The correlation between polychaete burrow-entrance diameter and polychaete length could explain the ant selection. These results suggest that there is an active selection of prey based on the diameter of burrow entrances. Additionally, competition with other predators may also be enhanced since ants selectively prey on the large polychaetes, which could have an effect on prey population structure (Kent \& Day 1983, Kalejta 1993).

\section{Implications for other systems}

Movement of nutrients, detritus and organisms among habitats could be a common phenomenon, with important effects on the dynamics and structure of both communities (Polis \& Hurd 1996). We have shown that predation by ants is common in this SW Atlantic estuarine system. In South America, the fire ant Solenopsis richteri is naturally distributed in the coastal areas from Rio Grande do Sul $\left(32^{\circ} \mathrm{S}\right.$, Brazil) to Bahía Blanca $\left(38^{\circ} \mathrm{S}\right.$, Argentina). This area comprises several estuarine habitats with similar species composition to our study site, and thus predation in the intertidal is likely. Even more interesting is the fact that fire ants are successfully invading North America and Europe, and predation on intertidal inhabitants has already been reported (i.e. Allen et al. 2001a,b). Our results suggest that predation on polychaetes by these invading ants may be expected.

Acknowledgments. We are grateful to Dr. A. Farji-Brener for his helpful suggestions and species determination and Dr. E. Adams for his useful comments. Dr. M. Bertness and 3 anonymous reviewers made very useful comments on a previous manuscript. Support for this project was provided by grants from CONICET (PIA 6097, PIP 0686) and IFS (Sweden, No. A/2501-2), all granted to O.I. G.P. was supported by a fellowship from CONICET (Argentina), and this study is part of her $\mathrm{PhD}$ thesis.

\section{LITERATURE CITED}

Allen CR, Forys EA, Rice KG, Wojcik DP (2001a) Effects of fire ants (Hymenoptera: Formicidae) on hatching turtles and prevalence of fire ants on sea turtle nesting beaches in Florida. Flo Entomol 84:250-253

Allen CR, Rice KG, Wojcik DP, Percival HF (2001b) Effect of red imported fire ants envenomitazation on neonatal American alligators. J Herpetol 31:318-321

Bortolus A, Iribarne O (1999) Effects of the SW Atlantic burrowing crab Chasmagnathus granulata on a Spartina salt marsh. Mar Ecol Prog Ser 178:78-88

Botto F, Iribarne O (2000) Contrasting effects of two burrowing crabs (Chasmagnathus granulata and Uca uruguayensis) on sediment composition and transport in estuarine environments. Estuar Coast Shelf Sci 51:141-151 
Botto F, Iribarne O, Martinez M, Delhey K, Carrete M (1998) The effect of migratory shorebirds on the benthic fauna of three SW Atlantic estuaries. Estuaries 21:700-709

Botto F, Palomo G, Iribarne O, Martinez M (2000) The SW Atlantic burrowing crab Chasmagnathus granulata affects habitat use and foraging of migratory shorebirds. Estuaries 23:208-215

Buckley R (1980) Marine-terrestrial transfer by strandline foraging ants. Biotropica 12:314-315

Burger AE (1985) Terrestrial food webs in the sub-Antarctic: island effects. In: Siegfried WR, Condy PR, Laws RM (eds) Antarctic nutrient cycles and food webs. Springer, Berlin, p 582-591

Cabrera AL, Zardini EM (1993) Manual de la flora de los alrededores de Buenos Aires. Editorial Acme, Buenos Aires

Carver RE (1971) Procedures in sedimentary petrology. Wiley Interscience, New York

Choat JH (1982) Fish feeding and the structure of benthic communities in temperate waters. Annu Rev Ecol Syst 13: 423-449

Conover WJ (1980) Practical nonparametric statistics, 2nd edn. John Wiley \& Sons, New York

Due AD, Polis GA (1985) The biology of Vaejovis littoralis Williams, an intertidal scorpion from Baja California, Mexico. J Anim Ecol 207:563-580

Esselink P, Zwarts L (1989) Seasonal trend in burrow depth and tidal variation in feeding activity of Nereis diversicolor. Mar Ecol Prog Ser 56:243-254

Fasano JL, Hernández MA, Isla FI, Schnack EJ (1982) Aspectos evolutivos y ambientales de la laguna Mar Chiquita (provincia de Buenos Aires, Argentina). Int Symp Coastal Lagoons, Bordeaux, France. September 8-14, 1981. Oceanol Acta, p 285-292

FitzPatrick EA (1984) Suelos. Su formación, clasificación y distribución. Compañia Editorial Continental, Mexico City

Green WP, Pettry DE, Switzer RE (1999) Structure and hydrology of mounds of the imported fire ants in the southeastern United States. Geoderma 93:1-17

Gutierrez J, Iribarne O (1999) Role of Holocene beds of the stout razor clam Tagelus plebeius in structuring present benthic communities. Mar Ecol Prog Ser 185:213-228

Iribarne O, Martinez M (1999) Predation on the southwestern atlantic fiddler crab Uca uruguayensis by migratory shorebirds (Pluvialis dominica, P. squatarola, Arenaria interpres and Numenius phaeopus). Estuaries 22:47-54

Iribarne O, Bortolus A, Botto F (1997) Between-habitat differences in burrow characteristics and trophic modes in the south western Atlantic burrowing crab Chasmagnathus granulata. Mar Ecol Prog Ser 155:137-145

Isla FI, Gaido ES (2001) Evolución geológica de la laguna Mar Chiquita. In: Iribarne O (ed) Reserva de biosfera Mar Chiquita: características físicas, biológicas y ecológicas. Editorial Martin, Mar del Plata, p 19-30

Jaffe K (1993) Surfing ants. Flo Entomol 6:182-183

Kalejta B (1993) Intense predation cannot always be detected experimentally: a case study of shorebird predation on nereid polychaetes in South Africa. Neth J Sea Res 31: 385-393

Kent AC, Day RW (1983) Population dynamics of an infaunal polychaete: the effect of predators and an adult-recruit interaction. J Exp Mar Biol Ecol 73:185-203

Kusnezov N (1978) Hormigas argentinas: claves para su identificación. Edición Misceláneas, Tucumán

Langguth A (1975) Ecology and evolution of the South American canids. In: Fox MW (ed) The wild canids. Van Nostrand Reinhold, New York, p 192-206
Lofgren CS, Banks WA, Glancey BM (1975) Biology and control of imported fire ants. Annu Rev Entomol 20:1-30

Magurran AE (1988) Ecological diversity and its measurements. Princeton University Press, Princeton, NJ

Maitland DP, Maitland A (1994) Significance of burrowopening diameter as a flood-prevention mechanism for air-filled burrows of small intertidal arthropods. Mar Biol 119:221-225

Manly BFJ (1994) Multivariate statistical methods. A primer, 2nd edn. Chapman \& Hall/CRC, New York

Martinetto P (2001) Efecto de los cangrejales Chasmagnathus granulata en el uso de habitat de cangrejos, peces y zooplancton. In: Iribarne O (ed) Reserva de biosfera Mar Chiquita: características físicas, biológicas y ecológicas. Editorial Martin, Mar del Plata, p 165-170

Morrison LW (2000) Mechanisms of interespecific competition among an invasive and two native fire ants. Oikos 90: $238-252$

Moulis RA (1997) Predation by the imported fire ant (Solenopsis invicta) on loggerhead sea turtle (Caetta caretta). Chelon Conserv Biol 2:433-436

Munsell Color Company (2000) Munsell soil color charts. Munsell Color Company, GretagMacbeth, New Windsor

Navarrete SA, Castilla JC (1993) Predation by Norway rats in the intertidal zone of central Chile. Mar Ecol Prog Ser 92: 187-199

Neter J, Wasserman W, Kutner MH (1990) Applied linear models, regression, analysis of variance, and experimental designs. RD Irwin, Boston

Olivier SR, Escofet A, Penchazadeh P, Orensanz JM (1972a) Estudios ecológicos de la región estuarial de Mar Chiquita (Buenos Aires, Argentina), I. Las comunidades bentónicas. Anal Sociedad Científica Arg 193:237-262

Olivier SR, Escofet A, Penchazadeh P, Orensanz JM (1972b) Estudios ecológicos de la región estuarial de Mar Chiquita (Buenos Aires, Argentina), II. Relaciones tróficas interrespecíficas. Anal Sociedad Científica Arg 194:89-104

Orensanz JM, Estivariz MC (1971) Los anélidos poliquetos de aguas salobres de la provincia de Buenos Aires. Rev Mus La Plata Nueva Ser Secc Zool 11:95-112

Palomo G, Iribarne O (2000) Sediment bioturbation by polychaetes may promote sediment stability. Bull Mar Sci 67: $249-257$

Palomo G, Iribarne O, Martinez M (1999) The effect of seabirds guano on the benthic communities of a SW Atlantic coastal lagoon. Bull Mar Sci 65:119-128

Polis GA, Hurd SD (1996) Linking marine and terrestrial food webs: allochthonous input from the ocean supports high secondary productivity on small islands and coastal land communities. Am Nat 147:396-423

Porter SD, Tschinkel WR (1987) Foraging in Solenopsis invicta (Hymenoptera: Formicidae): effects of weather and season. Environ Entomol 16:802-808

Porter SD, Bhatkar AP, Mulder R, Vinson SB, Clair DJ (1991) Distribution and density of polygyne fire ants (Hymenoptera: Formicidae) in Texas. J Econ Entomol 84: 866-874

Porter SD, Williams DF, Patterson RS, Fowler HG (1997) Intercontinental differences in the abundance of Solenopsis fire ants (Hymenoptera: Formicidae): escape from natural enemies? Environ Entomol 26:373-384

Quammen ML (1984) Predation by shorebirds, fish, and crabs on invertebrates in intertidal mudflats: an experimental test. Ecology 65:529-537

Reta R, Martos P, Perillo GME, Piccolo MC, Ferrante A (2001) Características hidrográficas del estuario de la laguna Mar Chiquita. In: Iribarne O (ed) Reserva de biosfera Mar 
Chiquita: características físicas, biológicas y ecológicas. Editorial Martin, Mar del Plata, p 31-52

Rose MD, Polis GA (1998) The distribution and abundance of coyotes: the effects of allochthonous food subsidies from the sea. Ecology 79:998-1007

Ross KG, Trager JC (1990) Systematics and population genetics of fire ants (Solenopsis saevisima complex) from Argentina. Evolution 44:2113-2134

Schwindt E, Iribarne O (2000) Settlement sites, survival and effects on benthos of an introduced reef-building polychaete in a SW Atlantic. B Mar Sci 67:73-82

Schwindt E, Bortolus A, Iribarne O (2001) Invasion of a reefbuilder: impact on an estuarine benthic community. Biol Invasions 3:137-149

Sheldon JW (1991) Wild dogs: the natural history of the nondomestic canidae. Academic Press, New York

Sorensen AA, Busch TM, Vinson SB (1983) Behavior of worker subcastes in the fire ant, Solenopsis invicta, in response to proteinaceous food. Physiol Entomol 8:83-92

Tschinkel WR (1988) Distribution of the fire ants Solenopsis invicta and $S$. geminata (Hymenoptera: Formicidae) in Northern Florida in relation to habitat and disturbance. Ann Entomol Soc Am 81:76-81

Editorial responsibility: Ronald Karlson (Contributing Editor), Newark, Delaware, USA
Virstein RW (1977) The importance of predation by crabs and fish on coastal lagoon benthic infauna in Chesapeake Bay. Ecology 58:1199-1217

Wangberg JK, Ewig JD Jr, Pinson CK (1980) The relationship of Solenopsis invicta Buren to soils of East Texas. Southwest Entomol 5:16-18

Wilmers TJ, Wilmers ES, Miller M, Wells P (1996) Imported fire ants (Solenopsis invicta): a growing menace to sea turtle nests in Key West National Wildlife Refuge In: Keinath JA, Barnard DE, Musick JA, Bell BA (eds) Proc 15th Annual Workshop on Sea Turtle Biology and Conservation. NOAA Tech Memo NMFS-SEFSC-387, p 341-343

Wilson WH Jr (1994) The effects of episodic predation by migratory shorebirds in Gray Harbor, Washington. J Exp Mar Biol Ecol 177:15-25

Woodin SA (1978) Refuges, disturbance and community structure: a marine soft-bottom example. Ecology 59: 274-284

Yensen N, Yensen E, Yensen D (1980) Intertidal ants from the Gulf of California, Mexico. Annu Rev Entomol Soc Am 73: 266-269

Zar JH (1999) Biostatistical analysis, 4th edn. Prentice-Hall, Englewood Cliffs, New York

Submitted: October 15, 2002; Accepted: January 2, 2003

Proofs received from author(s): April 28, 2003 